\title{
Plasma NT-proBNP as a More Reliable Biomarker of Endogenous Cardiac Natriuretic Peptides Than BNP During Carperitide Infusion
}

\author{
Keizo Nishiyama, ${ }^{1}$ MD, Takayoshi Tsutamoto, ${ }^{1}$ MD, Toshinari TanaKa, ${ }^{1}$ MD, \\ Masanori FuJII, ${ }^{1} \mathrm{MD}$, Takashi Yaмамото,${ }^{1} \mathrm{MD}$, Masayuki YamajI, ${ }^{1} \mathrm{MD}$, \\ and Minoru HorIE, ${ }^{1} \mathrm{MD}$
}

\section{SUMMARY}

Because both atrial natriuretic peptide (ANP) and brain natriuretic peptide (BNP) competitively bind to natriuretic peptide receptors but not N-terminal proBNP (NT-proB$\mathrm{NP}$ ), the diagnostic value of BNP as a marker of the severity of heart failure in comparison with NT-proBNP during exogenous ANP (carperitide) infusion remains unclear.

Forty-two patients with CHF (NYHA class III or IV) treated with the infusion of carperitide were included in the present study. We measured plasma levels of BNP and NT-proBNP at baseline and after the improvement of symptoms. We also measured these parameters before and 1 hour after stopping the infusion of carperitide.

After stopping the infusion of carperitide, the plasma BNP level was significantly decreased by about $20 \%$ (394 \pm 53.8 versus $312.8 \pm 46 \mathrm{pg} / \mathrm{mL}, P<0.0001)$ but plasma NT-proBNP did not change $(1674.5 \pm 282.1$ versus $1777.5 \pm 300.3 \mathrm{pg} / \mathrm{mL}, P=0.259)$. The molar ratio of plasma BNP/NT-proBNP was significantly higher during carperitide infusion $(0.74 \pm 0.08)$ than those at baseline $(0.63 \pm 0.06)$ and after stopping carperitide $(0.59 \pm 0.07)$.

During carperitide infusion, plasma NT-proBNP may be a more reliable marker of endogenous cardiac natriuretic peptides than plasmaBNP, which may be increased by carperitide infusion. (Int Heart J 2009; 50: 183-190)

Key words: Atrial natriuretic peptide, Brain natriuretic peptide, NT-proBNP, Carperitide

B RAIN or B-type natriuretic peptide (BNP) is synthesized as preproBNP mainly in the ventricular myocardium. During ventricular myocyte stretching, preproBNP is enzymatically cleaved to proBNP and released in the form of hormonally active BNP and inactive NT-proBNP. Atrial natriuretic peptide (ANP) and BNP have biologic effects such as natriuresis, diuresis, vasodilatation, and

From the ${ }^{1}$ Department of Cardiovascular and Respiratory Medicine, Shiga University of Medical Science, Shiga, Japan.

Address for correspondence: Takayoshi Tsutamoto, MD, Cardiovascular and Respiratory Medicine, Shiga University of Medical Science, Tsukinowa, Seta, Otsu, Shiga 520-2192, Japan.

Received for publication July 17, 2008.

Revised and accepted October 23, 2008. 
inhibition of the renin-angiotensin-aldosterone system and sympathetic nervous system. ${ }^{1-4)}$ Several clinical studies have demonstrated that plasma levels of BNP and NT-proBNP are useful biomarkers to evaluate the severity and the prognosis of patients with heart failure. ${ }^{5-7)}$

Evaluation of the left ventricular filling pressure or pulmonary capillary wedge pressure is important, especially in patients with severe heart failure, however, direct hemodynamic measurements by Swan-Ganz catheters have not been regularly performed ${ }^{8-11)}$ and it has been often estimated by the plasma levels of ANP, BNP, and NT-proBNP and these peptides demonstrate almost equal values under various treatments for heart failure. ${ }^{12-16)}$ Because two endogenous natriuretic peptides, ANP and BNP, bind to natriuretic peptide receptors (NPR); NPR-A and NRP-C receptors with a relatively higher selectivity for ANP than $\mathrm{BNP},{ }^{17,18)}$ plasma levels of BNP may be affected by carperitide (ANP) infusion. Therefore, in the present study, we evaluated the influence of carperitide infusion on plasma levels of BNP in comparison with those of NT-proBNP.

\section{Methods}

Study population: The subjects were 42 patients with chronic $\mathrm{CHF}$, a left ventricular ejection fraction $(\mathrm{LVEF})<45 \%$, and New York Heart Association (NYHA) functional class III or IV who were admitted to our institution and whose symptoms improved to NYHA functional class II within 1 month following the initiation of standard therapy for $\mathrm{CHF}$, including carperitide infusion. Patients with severe CHF who needed cardiac resynchronization therapy, an implantable cardioverter-defibrillator, or other mechanical supports were excluded. Patients with unstable angina pectoris, renal failure (creatinine $>2.0 \mathrm{mg} / \mathrm{dL}$ ), liver dysfunction, cardiogenic shock, or hypotension defined as systolic blood pressure $<90 \mathrm{mmHg}$ were also excluded. Informed consent was obtained from all patients before participation in the study, according to the protocol approved by the Committee on Human Investigation at our institution.

Study protocol: On admission, blood samples were obtained for measurement of neurohumoral factors. Most patients were already receiving standard oral therapy. Infusion of carperitide was started at a dose of $0.02 \mu \mathrm{g} / \mathrm{kg} / \mathrm{minute}$, following which the dose was changed to $0.01-0.1 \mu \mathrm{g} / \mathrm{kg} /$ minute within 24 hours (mean $0.017 \mu \mathrm{g} / \mathrm{kg} / \mathrm{minute}$ ) to maintain the systolic blood pressure above $90 \mathrm{mmHg}$. During the study period, there was no restriction on additional intravenous and/ or oral treatments for heart failure. The infusion was continued for more than 2 days until symptomatic improvement to NYHA class II. After the improvement of symptoms (NYHA class II), we measured plasma levels of ANP, BNP, and NT-proBNP before and 1 hour after stopping the infusion of carperitide. We also 
measured the blood pressure and heart rate before and 1 hour after stopping the infusion of carperitide. Measurements were obtained early in the morning after patients rested in a supine position for 30 minutes. When blood sampling was obtained before and after stopping carperitide, medications were not changed for at least 24 hours before sampling. Renal function was represented by the estimated glomerular filtration rate (eGFR) according to the abbreviated MDRD equation. $^{19)}$

Neurohumoral measurements: Plasma levels of ANP and BNP were measured with a specific immunoradiometric assay using commercial kits (Shionogi,

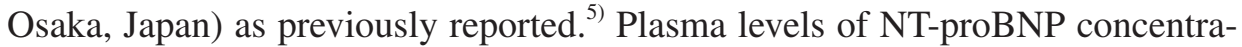
tions were measured using an Elecsys proBNP sandwich immunoassay (Roche Diagnostics, Basel, Switzerland), as previously reported. ${ }^{20)}$

Statistical analysis: All results are expressed as the mean \pm SE. Univariate analyses were performed using Student's $t$ test. Differences in mean levels of ANP, BNP, and NT-proBNP between the two groups were tested by Wilcoxon's ranksum test for paired values. Differences in the molar ratio of plasma BNP/NT-pro BNP was tested for significance using the one-way repeated measures ANOVA because the molar ratio of plasma BNP/NT-proBNP was normally distributed. A value of $P<0.05$ was considered significant.

\section{RESULTS}

Clinical characteristics (Table I): The causes of heart failure were dilated cardiomyopathy in 35 patients and ischemic cardiomyopathy in 7 patients. At admission, 15 patients were in NYHA functional class III, and 27 were in class IV. Most patients were already receiving the standard oral therapy. After hospitalization, 28 patients received furosemide infusions, 18 patients dopamine infusions, 6 patients dobutamine infusions, and 6 patients milrinone infusions.

Time courses of plasma BNP and NT-proBNP before and after stopping carperitide: The duration of carperitide infusion to obtain symptomatic improvement to NYHA class II ranged from 2 to 28 days (mean 8.8 days, median 7.5 days). Neither heart rate nor mean blood pressure showed any change 1 hour after stopping carperitide infusion $(76 \pm 2.2$ versus $78 \pm 2.4$ beats/minute and $72 \pm 2.0$ versus $71 \pm 1.8 \mathrm{mmHg})$. The plasma levels of ANP $(488.0 \pm 11.6$ versus $125.1 \pm$ $16 \mathrm{pg} / \mathrm{mL}, P<0.0001)$ and BNP $(394.0 \pm 53.8$ versus $312.8 \pm 46.0 \mathrm{pg} / \mathrm{mL}, P=$ $0.0002)$ significantly decreased after stopping carperitide, but plasma levels of NT-proBNP did not change after stopping carperitide (Figure 1). There was a significant positive correlation between percent-changes in ANP levels and percent-changes in BNP before and after stopping carperitide $(r=0.425, P=$ 0.0032), but there was no correlation between percent-changes in ANP levels 
Table I. Baseline Characteristics $(n=42)$

\begin{tabular}{lc}
\hline Age (years) & $60.2 \pm 1.4$ \\
Body weight (kg) & $63.9 \pm 2.0$ \\
Body mass index & $23.4 \pm 0.6$ \\
Gender (male / female) & $37 / 5$ \\
NYHA class (III/IV) & $15 / 27$ \\
Hyperlipidemia (\%) & $9(21.4)$ \\
Diabetes mellitus (\%) & $8(19.0)$ \\
Etiology of chronic heart failure & \\
Ischemic cardiomyopathy (\%) & $7(16.7)$ \\
Dilated cardiomyopathy (\%) & $35(83.3)$ \\
Sinus rhythm $(\%)$ & $24(57.1)$ \\
Heart rate (beats/minute) & $83.2 \pm 2.5$ \\
Systolic blood pressure (mmHg) & $100.9 \pm 3.8$ \\
Diastolic blood pressure (mmHg) & $65.9 \pm 1.9$ \\
Serum creatinine (mg/dL) & $1.15 \pm 0.07$ \\
eGFR (mL/minute) & $57.7 \pm 4.5$ \\
Atrial natriuretic peptide (pg/mL) & $207.2 \pm 17.4$ \\
Brain natriuretic peptide (pg/mL) & $720.1 \pm 71.3$ \\
N-terminal pro-BNP (pg/mL) & $3443.3 \pm 486.2$ \\
Norepinephrine (pg/mL) & $997.4 \pm 83.4$ \\
Aldosterone (pg/mL) & $245.6 \pm 51.3$ \\
Ejection fraction (\%) & $35.7 \pm 1.9$ \\
Baseline therapy & \\
ACE-I (\%) & $18(42.8)$ \\
ARB (\%) & $16(38.0)$ \\
Beta-blockers (\%) & $20(47.6)$ \\
Spironolactone $(\%)$ & $31(73.8)$ \\
Loop diuretics $(\%)$ & $38(90.4)$ \\
Digitalis $(\%)$ & $25(60.0)$ \\
Statin (\%) & $4(10.0)$
\end{tabular}

ACE-I indicates angiotensin-converting enzyme inhibitors; $\mathrm{ARB}$, angiotensin receptor blockers; BNP, brain natriuretic peptide; and eGFR, estimated glomerular filtration rate.
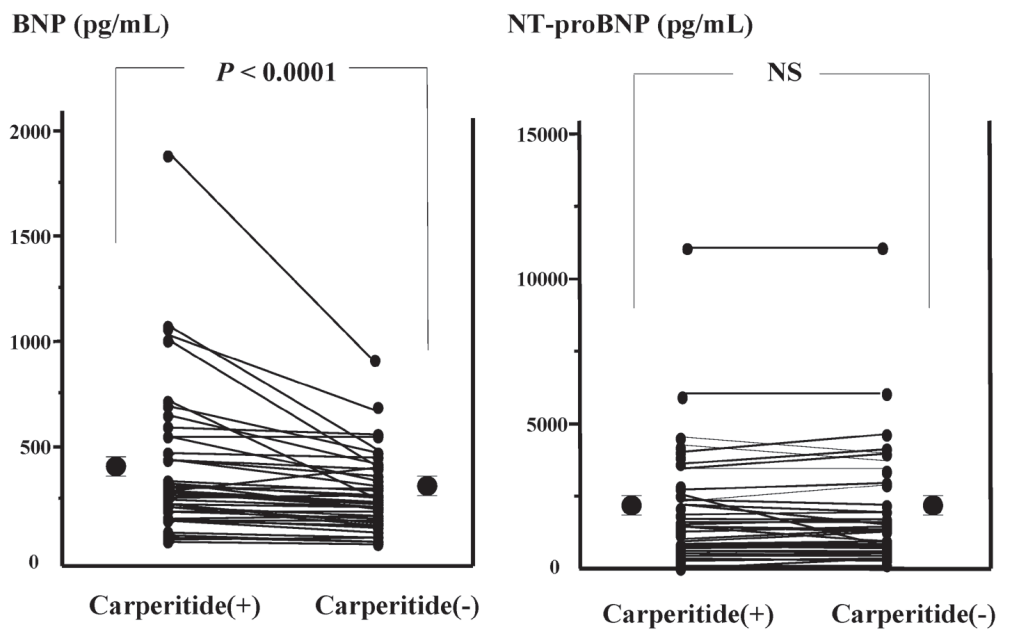

Figure 1. Plasma levels of BNP and NT-proBNP before and after stopping carperitide. BNP indicates brain natriuretic peptide and NT-proBNP, N-terminal pro brain natriuretic peptide. 
and percent-change in NT-proBNP.

Molar ratio of plasma BNP/NT-proBNP and renal function during carperitide infusion (Table II): Both BNP and NT-proBNP were significantly decreased and the molar ratio of plasma BNP/NT-proBNP was significantly increased after carperitide infusion (Figure 2). Serum creatinine was increased and eGFR was decreased after carperitide infusion. The molar ratio of plasma BNP/NT-proBNP

Table II. Plasma Levels of ANP, BNP, and NT-proBNP, Molar ratio of BNP/NT-proBNP, and Renal Function at Baseline and After 7 Day Treatment for Heart Failare

\begin{tabular}{lccc}
\hline Parameter & $\begin{array}{c}\text { Baseline } \\
(n=42)\end{array}$ & $\begin{array}{c}7 \text { days after } \\
(n=42)\end{array}$ & $P$ \\
\hline ANP $(\mathrm{pg} / \mathrm{mL})$ & $207.2 \pm 17.4$ & $488.0 \pm 11.6$ & $<0.001$ \\
$\quad($ median$)$ & $(207.5)$ & $(322.0)$ & \\
BNP $(\mathrm{pg} / \mathrm{mL})$ & $720.1 \pm 71.3$ & $394.0 \pm 53.8$ & $<0.001$ \\
$\quad($ median$)$ & $(477.5)$ & $(348.6)$ & \\
NT-proBNP $(\mathrm{pg} / \mathrm{mL})$ & $3443.3 \pm 486.2$ & $1674.5 \pm 282.1$ & 0.006 \\
$\quad($ median$)$ & $(2511)$ & $(1342)$ & \\
Molar ratio of BNP $(\mathrm{pmol} / \mathrm{L}) / \mathrm{NT}-\mathrm{proBNP}(\mathrm{pmol} / \mathrm{L})$ & $0.63 \pm 0.060$ & $0.74 \pm 0.08$ & 0.0025 \\
Serum creatinine $(\mathrm{mg} / \mathrm{dL})$ & $1.15 \pm 0.07$ & $1.25 \pm 0.08$ & 0.029 \\
eGFR (mL/minute) & $57.7 \pm 4.5$ & $59.30 \pm 4.0$ & 0.0025 \\
\hline
\end{tabular}

ANP indicates atrial natriuretic peptide; BNP, brain natriuretic peptide; NT-proBNP, N-terminal pro brain natriuretic peptide; and eGFR, estimated glomerular filtration rate.

BNP (pmoL/L) / NT-proBNP (pmoL/L)

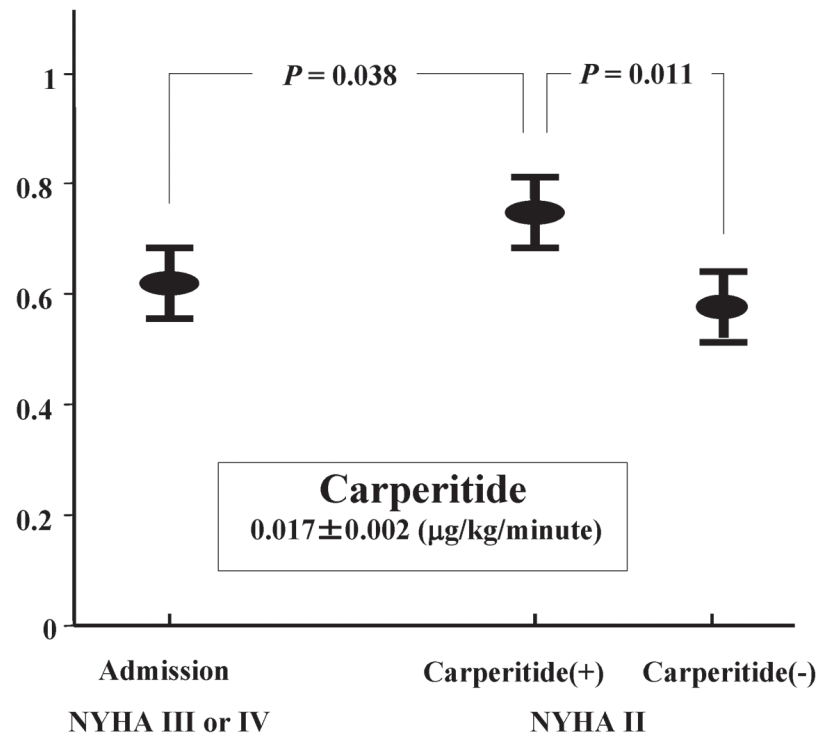

Figure 2. Time course of the molar ratio of BNP/NT-proBNP in patients with heart failure during carperitide infusion.

BNP indicates brain natriuretic peptide and NT-proBNP, N-terminal pro brain natriuretic peptide. 
was significantly increased during carperitide infusion and decreased after stopping carperitide.

\section{Discussion}

In clinical practice, evaluation of the severity of heart failure and estimation of left ventricular filling pressure or pulmonary capillary wedge pressure are important. These have often been judged by the plasma levels of ANP, BNP, and NT-proBNP, which demonstrate almost equal values under various treatments for heart failure. ${ }^{12-16)}$ However, the present study suggests that during carperitide infusion, a sham elevation of plasma BNP (about 20\% increases) occurs and NT-proBNP is a more reliable marker of endogenous cardiac natriuretic peptides than BNP.

Both ANP and BNP have biologic effects such as natriuresis, diuresis, vasodilatation, and suppression of the renin-angiotensin-aldosterone system and the sympathetic system via increases in the intracellular cGMP level after binding to NPR-A. Both ANP and BNP bind to natriuretic peptide receptors such as NPR-A and clearance receptors with a relatively higher selectivity of ANP than BNP, and ANP binds preferentially to NPR-A. ${ }^{17,18)}$ However, NT-proBNP does not have bioactivity, and it is metabolized without binding to a specific receptor after being secreted into the blood. In this study, the plasma BNP level was significantly decreased (about 20\%) after stopping carperitide without any changes in hemodynamics and symptoms, but the plasma NT-proBNP level did not change (Figure 1). In addition, the molar ratio of the BNP/NT-proBNP was significantly decreased after stopping carperitide (Figure 2). This study suggests that exogenous infusion of carperitide and BNP binds NPR-A receptors in a competitive manner. Therefore, the plasma NT-proBNP level is a more accurate index of the severity of CHF than the plasma BNP level during carperitide infusion.

Previous studies have reported that plasma BNP and NT-proBNP are affected by renal dysfunction, ${ }^{21-23)}$ and NT-proBNP is more influenced by renal dysfunction than BNP, ${ }^{24,25)}$ suggesting that the molar ratio of BNP/NT-proBNP is slightly decreased due to the decreased eGFR by heart failure treatments including carperitide. However, in this study, the molar ratio of BNP/NT-proBNP was significantly increased after carperitide infusion. In addition, the molar ratio of plasma BNP/NT-proBNP was significantly decreased after stopping carperitide, suggesting that the molar ratio of plasma BNP/NT-proBNP was affected by carperitide.

There are several limitations to this study design. First, we did not perform direct hemodynamic measurements using a Swan-Ganz catheter during the study 
period. Although the general condition was stable and neither the blood pressure nor heart rate changed before and after stopping carperitide, plasma levels of aldosterone and endothelin-1 were increased after the withdrawal of carperitide as previously reported. ${ }^{4)}$ Therefore, in some patients left ventricular filling pressure may be increased after withdrawal of carperitide infusion. However, plasma BNP levels were significantly decreased in contrast to plasma NT-proBNP levels. Second, we measured plasma BNP and NT-proBNP before and 1 hour after the cessation of carperitide. Judging from the half-life of NT-proBNP (60 minutes-120 minutes), blood sampling should be collected after several hours, however, it was difficult to keep the patients resting in the supine position for several hours in the morning without a meal and their oral medication. Third, in the present study, the influence of individual variations in BNP and NT-proBNP cannot be ignored. ${ }^{26)}$

In conclusion, during carperitide infusion, plasma NT-proBNP may be a more reliable marker of endogenous cardiac natriuretic peptides than plasma BNP, which may be increased (about 20\% elevation) by ANP infusion, probably due to competitive binding of exogenous ANP to natriuretic peptide receptors.

\section{ACKNOWLEDGEMENTS}

We wish to thank Ms. Yohko Watanabe for her excellent technical assistance. We also express thanks to Mr. Daniel Mrozek for assistance in preparing the manuscript. This study was supported by a Grant-in-Aid for Scientific Research in Japan.

\section{REFERENCES}

1. Saito Y, Nakao K, Nishimura K, et al. Clinical application of atrial natriuretic polypeptide in patients with congestive heart failure: beneficial effects on left ventricular function. Circulation 1987; 76: 115-24.

2. Abraham WT, Lowes BD, Ferguson DA, et al. Systemic hemodynamic, neurohormonal, and renal effects of a steady-state infusion of human brain natriuretic peptide in patients with hemodynamically decompensated heart failure. J Card Fail 1998; 4: 37-44.

3. Hayashi M, Tsutamoto T, Wada A, et al. Intravenous atrial natriuretic peptide prevents left ventricular remodeling in patients with first anterior acute myocardial infarction. J Am Coll Cardiol 2001; 37: 1820-6.

4. Ishikawa $\mathrm{C}$, Tsutamoto $\mathrm{T}$, Wada $\mathrm{A}$, et al. Inhibition of aldosterone and endothelin-1 by carperitide was attenuated with more than 1 week of infusion in patients with congestive heart failure. J Cardiovasc Pharmacol 2005; 46: 513-8.

5. Tsutamoto T, Wada A, Maeda K, et al. Attenuation of compensation of endogenous cardiac natriuretic peptide system in chronic heart failure: prognostic role of plasma brain natriuretic peptide concentration in patients with chronic symptomatic left ventricular dysfunction. Circulation 1997; 96: 509-16.

6. Hartmann F, Packer M, Coats AJ, et al. Prognostic impact of plasma N-terminal pro-brain natriuretic peptide in severe chronic congestive heart failure: a substudy of the Carvedilol Prospective Randomized Cumulative Survival (COPERNICUS) trial. Circulation 2004; 110: 1780-6.

7. Tsutamoto T, Sakai H, Nishiyama K, et al. Direct comparison of transcardiac increase in brain natriu- 
retic peptide (BNP) and $\mathrm{N}$-terminal proBNP and prognosis in patients with chronic heart failure. Circ J 2007; 71: 1873-8.

8. Nohria A, Tsang SW, Fang JC, et al. Clinical assessment identifies hemodynamic profiles that predict outcomes in patients admitted with heart failure. J Am Coll Cardiol 2003; 41: 1797-804.

9. Binanay C, Califf RM, Hasselblad V, et al. Evaluation study of congestive heart failure and pulmonary artery catheterization effectiveness: the ESCAPE trial. JAMA 2005; 294: 1625-33.

10. Shah MR, Hasselblad V, Stevenson LW, et al. Impact of the pulmonary artery catheter in critically ill patients: meta-analysis of randomized clinical trials. JAMA 2005; 294: 1664-70.

11. Nieminen MS, Böhm M, Cowie MR, et al. Executive summary of the guidelines on the diagnosis and treatment of acute heart failure: the Task Force on Acute Heart Failure of the European Society of Cardiology. Eur Heart J 2005; 26: 384-416.

12. Tsutamoto T, Kinoshita M, Nakae I, et al. Absence of hemodynamic tolerance to nicorandil in patients with severe congestive heart failure. Am Heart J 1994; 127: 866-73.

13. Haug C, Metzele A, Kochs M, Hombach V, Grünert A. Plasma brain natriuretic peptide and atrial natriuretic peptide concentrations correlate with left ventricular end-diastolic pressure. Clin Cardiol 1993; 16: 553-7.

14. Maeda K, Tsutamoto T, Wada A, Hisanaga T, Kinoshita M. Plasma brain natriuretic peptide as a biochemical marker of high left ventricular end-diastolic pressure in patients with symptomatic left ventricular dysfunction. Am Heart J 1998; 135: 825-32.

15. Parsonage WA, Galbraith AJ, Koerbin GL, Potter JM. Value of B-type natriuretic peptide for identifying significantly elevated pulmonary artery wedge pressure in patients treated for established chronic heart failure secondary to ischemic or idiopathic dilated cardiomyopathy. Am J Cardiol 2005; 95: 883-5.

16. Larsen AI, Dickstein K, Ahmadi NS, Aarsland T, Kvaløy JT, Hall C. The effect of altering haemodynamics on the plasma concentrations of natriuretic peptides in heart failure. Eur J Heart Fail 2006; 8: 628-33.

17. Suga S, Nakao K, Hosoda K, et al. Receptor selectivity of natriuretic peptide family, atrial natriuretic peptide, brain natriuretic peptide, and C-type natriuretic peptide. Endocrinology 1992; 130: 229-39.

18. de Lemos JA, McGuire DK, Drazner MH. B-type natriuretic peptide in cardiovascular disease. Lancet 2003; 362: 316-22.

19. Harmoinen A, Lehtimäki T, Korpela M, Turjanmaa V, Saha H. Diagnostic accuracies of plasma creatinine, cystatin C, and glomerular filtration rate calculated by the Cockcroft-Gault and Levey (MDRD) formulas. Clin Chem 2003; 49: 1223-5.

20. Tsutamoto T, Sakai H, Ishikawa C, et al. Direct comparison of transcardiac difference between brain natriuretic peptide (BNP) and N-terminal proBNP in patients with chronic heart failure. Eur J Heart Fail 2007; 9: 667-73.

21. McCullough PA, Duc P, Omland T, et al. B-type natriuretic peptide and renal function in the diagnosis of heart failure: an analysis from the Breathing Not Properly Multinational Study. Am J Kidney Dis 2003; 41: 571-9.

22. Luchner A, Hengstenberg C, Löwel H, Riegger GA, Schunkert H, Holmer S. Effect of compensated renal dysfunction on approved heart failure markers: direct comparison of brain natriuretic peptide (BNP) and N-terminal proBNP. Hypertension 2005; 46: 118-23.

23. Tsutamoto T, Wada A, Sakai H, et al. Relationship between renal function and plasma brain natriuretic peptide in patients with heart failure. J Am Coll Cardiol 2006; 47: 582-6.

24. Forfia PR, Watkins SP, Rame JE, Stewart KJ, Shapiro EP. Relationship between B-type natriuretic peptides and pulmonary capillary wedge pressure in the intensive care unit. J Am Coll Cardiol 2005; 45: 1667-71.

25. Vickery S, Price CP, John RI, et al. B-type natriuretic peptide (BNP) and amino-terminal proBNP in patients with CKD: relationship to renal function and left ventricular hypertrophy. Am J Kidney Dis 2005; 46: 610-20.

26. Bruins S, Fokkema MR, Römer JW, et al. High intraindividual variation of B-type natriuretic peptide (BNP) and amino-terminal proBNP in patients with stable chronic heart failure. Clin Chem 2004; 50: 2052-8. 